丸山 隆志 ${ }^{12)}$, 村垣 善浩1)2), 新田 雅之 ${ }^{122}$, 斎藤 太-112), 田村 学 $^{2)}$, 伊関 洋1)2),

岡田 芳和 ${ }^{12}$ )

1）東京女子医科大学脳神経外科, 2) 同 先端生命医科学研究所先端工学外科学分野

\title{
Glioma Surgery based on Anatomical Structure of the White Matter
}

\author{
Takashi Maruyama, M.D., Ph.D. ${ }^{1) 2}$, Yoshihiro Muragaki, M.D., Ph.D. ${ }^{1) 2}$, \\ Masayuki Nitta, M.D., Ph.D. ${ }^{1) 2}$, Taichi Saito, M.D., Ph.D. ${ }^{1) 2)}$, Manabu Tamura, M.D., Ph.D. ${ }^{2)}$, \\ Hiroshi Iseki, M.D., Ph.D. ${ }^{12)}$, and Yoshikazu Okada, M.D., Ph.D. ${ }^{12)}$
}

1) Department of Neurosurgery, Tokyo Women's Medical University, 2) Faculty of Advanced Techno-Surgery, Institute of Advanced Biomedical Engineering \& Science, Graduate School of Medicine, Tokyo Women's Medical University

The primary aim of glioma surgery is to achieve a balance between maximum tumor removal and minimal functional morbidity. The advent of awake surgery has greatly increased the number of patients with tumors in or around the eloquent language areas undergoing extensive removal. Preoperative anatomical evaluation modalities, such as diffusion tensor imaging (DTI) tractography or color mapping, are used to visualize the subcortical neuronal network in the white matter. This structural information can help predict further tumor extension and neuronal damage adjacent to the surrounding area of tumor. To achieve successful functional evaluation and maximum tumor removal without surgical complication, we must be well aware of the symptomatic evaluation following electrical stimulation. In the white matter, identifying the short association fibers and the long association fibers involving the association with language function are the key for successful resection. In our report, an overview of the anatomical structures and the clinical symptoms related to the language area encounterd in glioma removal surgery are reported.

(Received September 30, 2014; accepted November 27, 2014)

Key words : glioma, awake surgery, association fiber, cortical mapping Jpn J Neurosurg（Tokyo）24: 76-84, 2015

\section{はじめに}

グリオーマ手術において，白質解剖を熟知することは 摘出範囲の決定, 合併症を予防するうえで不可欠である.

グレード 2, 3 グリオーマでは 20〜 40 歳の若年をピー クに，無症状またはてんかん発作にて偶然発見される場 合が多い. 長期生存が期待できる腫瘍である以上，手術 の目的は組織診断の確定と摘出率の向上によるてんかん 発作のコントロールや, 生存期間の延長といった治療成
績の改善であるとともに，摘出術による合併症の予防に 努めなければならない. Functional MRI や tractography, 拡散テンソル法による color map などによる術前画像に て腫瘍の主座，周囲を取り巻く神経線維の描出を行うこ とで，近接する神経線維の障害による合併症の予測が可 能となる。すなわち術前の白質解剖に基づく摘出計画の 立案がより重要となった ${ }^{12)}{ }^{16) 20)}$ 。本稿では主として言語 機能の温存を目的とした覚醒下摘出術に必要な白質解剖 を中心に解説する。なお，言語に関する神経連絡線維の

連絡先：丸山隆志， $\bar{\top} 162-8666$ 新宿区河田町 8-1 東京女子医科大学脳神経外科

Address reprint requests to: Takashi Maruyama, M.D., Ph.D., Department of Neurosurgery, Tokyo Women's Medical University, 8-1 Kawadacho, Shinjuku-ku, Tokyo 162-8666, Japan 
Table 1 White matter gyral segment sectors

\begin{tabular}{l|c|l}
\hline \multicolumn{1}{c|}{ Composition } & Sector & \multicolumn{1}{c}{ Description } \\
\hline Gray matter & 0 & Cortical sector \\
Peripheral white matter & 1 & Subcortical sector \\
& 2 & Subgyral sector \\
& 3 & Gyral sector \\
Central white matter & 4 & Lobar sector \\
\hline
\end{tabular}

構成と機能については近年の研究にてより複雑かつ広範 囲の領域の関与が指摘されている ${ }^{31)}$ 。 また，グリオーマ に対する覚醒下手術中に観察される神経症状は, 限定さ れた時間とタスクの中で電気刺激により誘発された症状 であることから，術後に典型的な言語障害を呈さない場 合も多い. 術中に症状を呈したすべての言語関連線維を 温存するべきかについては議論が多く, 今後の症例経験 の集積の中で検討すべき問題である.

\section{グリオーマの浸潤形式}

大脳皮質は新皮質，古皮質，旧皮質に区分されること が知られている。これに対し連合線維の走行に応じた分 類として Yasargil ら ${ }^{42)}$ は正常な白質構造を灰白質（gray matter), 未梢性白質 (peripheral white matter), 中心性 白質 (central white matter) の 3 層に区分している. Peripheral white matter はさらに 4 つの sector に分かれ ており, 浅層より subcortical sector, subgyral sector, gyral sector, lobar sector と呼ばれる（Table 1, Fig. 1). 神経連絡線維は, その走行から short association fiber, long association fiber, commisural fiber に分類される. そ れぞれの線維は，機能や解剖学的連続性をもって白質内 を走行する。グリオーマの発生から周囲への浸潤までの パターンを一元的に語ることは困難である。しかし，概 念的には早期に subcortical, subgyral sector に発生した 腫瘍細胞が連結する軸索 (axon) に従って浸潤を開始す る. 次に subcortical sector を主として走行するU-fiber など，いわゆる short association fiber を介して隣接する 脳回に浸潤する。さらに浸潤が進むと long association fiber や commisural fiber を介して深部白質や対側へと伸 展する ${ }^{42)}$. MRI や PET などによる術前評価にて腫瘍の 辺縁がどの sector に到達しているかを予測することは， 目標とする摘出範囲を想定すると同時に今後の浸潤方向 を予測するために役立つ。

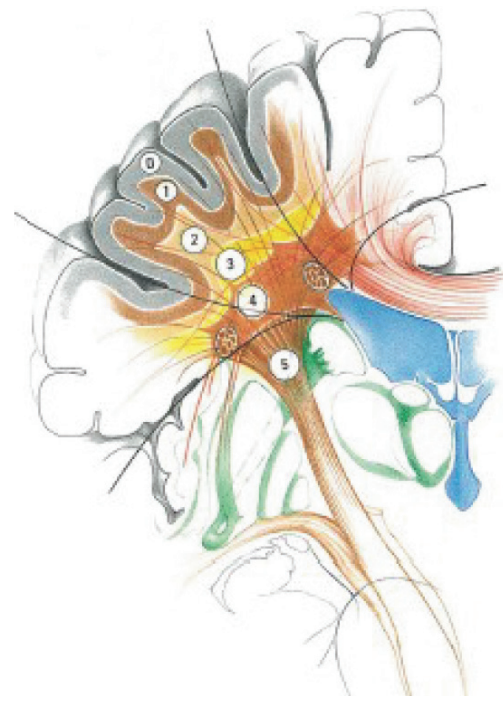

Fig. 1 Artistic diagram of the white matter sectors within a gyral segment (coronal section)

0 Cortex (gray)

1 Subcortical (brown)

2 Subgyral (light brown)

3 Gyral (yellow)

4 Lobar (dark brown)

5 Capsular, pyramidal 36.)

(Reprinted with permission from Reference

\section{言語に関する神経連絡線維}

言語機能の温存を目的としたグリオーマ摘出の場合, 言語機能に関連する注意するべき連合線維として(1)上縦 束 (superior longitudinal fasciculus : SLF)，(2)上前頭後頭 束 (superior fronto-occipital fasciculus : SFOF), (3)下前頭 後頭束 (inferior fronto-occipital fasciculus : IFOF), (4)下 縦束 (inferior longitudinal fasciculus : ILF), 鉤状束 (uncinate fasciculus：UF）等が知られている（Fig. 2, 3).

\section{上前頭後頭束}

SFOF は前頭葉の中，下前頭回から頭頂葉を経由し後 頭葉までを連絡する線維束である。深部白質において側 脳室体部の上外側角に接し，尾状核体部の上外側，放線 冠の内方を前後に走行する．放線冠により外側には上縦 束が，内側には上前頭後頭束が区別される．SFOF は梁 下束ともいわれ，言語機能の中でも言語始動障害に関す る情報伝達をつかさどるといわれる，主に上前頭回に位 置するグリオーマの摘出の際に関係する線維である. 


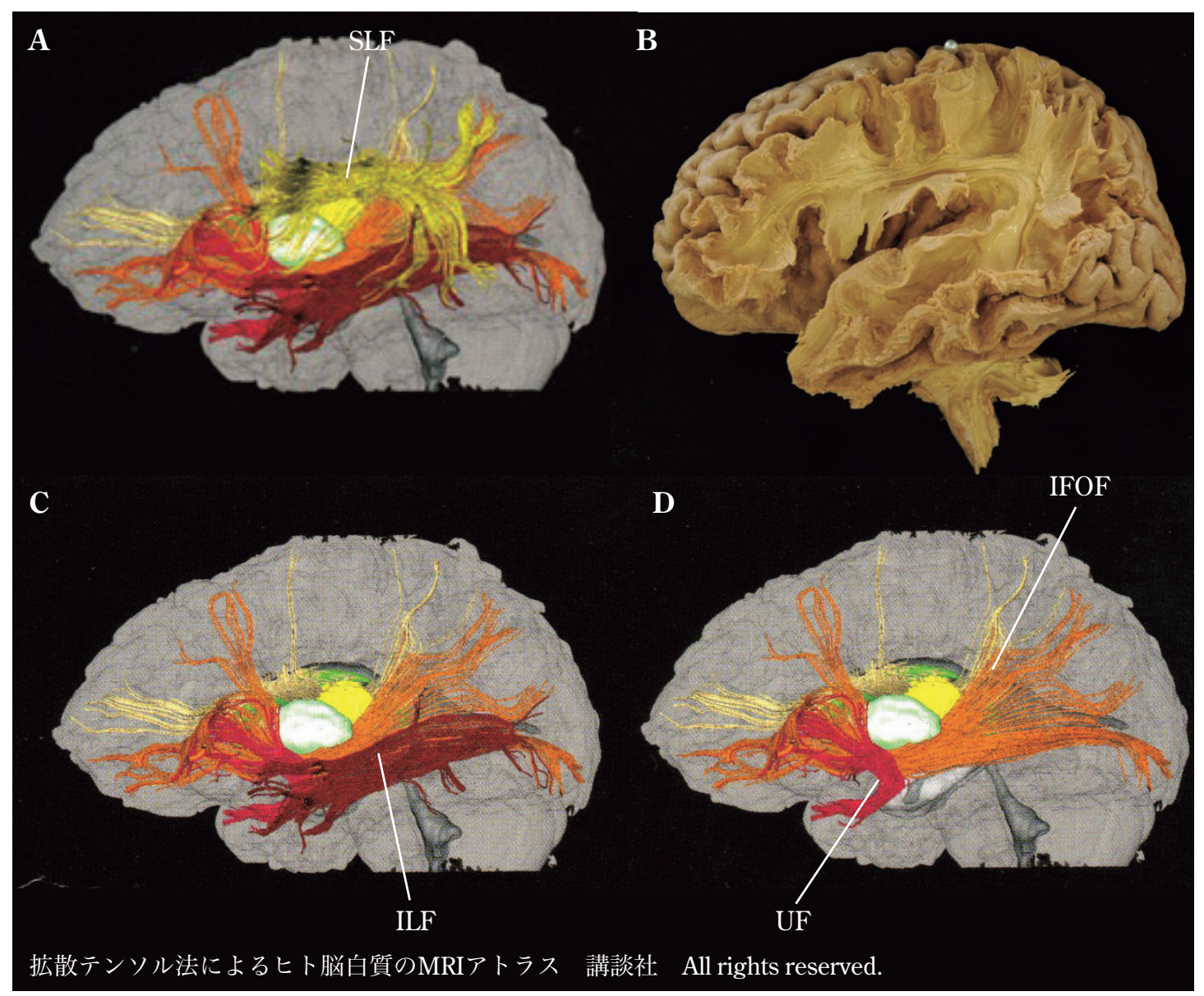

Fig. 2 3D-model of association fiber

A : Lateral view.

B : Fiber dissection of the lt cerebral hemisphere.

C : View after removing the SLF (yellow).

D : View after removing the SLF (yellow) and the ILF (brown).

Yellow: superior longitudinal fasciculus (SLF), Brown: inferior longitudinal fasciculus (ILF),

Orange : inferior fronto-occipital fasciculus (IFOF), Red: uncinated fasciculus (UF)

\section{上縦束}

前頭葉の下，中前頭回から発し島上端内側，前障の上 縁を経由し, 前頭葉, 頭頂葉, 後頭葉を連絡する。側脳 室体部の上外側角に接し, 島回後方で弓状にカーブし側 頭葉に向かう。上縦束を構成する要素にはいくつかの説 があり, Makris ${ }^{23)}$ からは以下の 4 つの要素から構成され ていることが報告されている（Fig. 3).

SLF I : 前頭葉背側, 内側皮質, 補足運動野と上頭頂 皮質へと投射し，運動制御に関わつていると考えられて いる.

SLF II：上縦束の主要な要素で, 下尾側頭頂皮質 (caudal-inferior parietal cortex） から背外側前頭前皮質（dorsolateral prefrontal cortex)へと投射される. 空間注意と視 覚，眼球運動機能に関与する下尾側頭頂皮質（caudalinferior parietal cortex)に接続することから視覚空間認知 に関する情報を連絡すると考えられている。

SLF III : 縁上回から腹側前運動野と前頭前野へと投射 する。腹側中心前回からの情報を吻側下頭頂皮質へと連 絡していることから，言語の調音などの体性感覚情報を 腹側前運動野，弁蓋部，縁上回，前頭前野などのワーキ ングメモリーに関連する皮質へと連絡していると考えら れている.

弓状束：中，下前頭回から外包を経由し，縁上回の深 部を通過し上側頭回を連絡する。運動性言語野と感覚性 言語野を連絡する主たる経路と考えられ，障害により伝 導失語を呈する。弓状束はより広く上，中側頭回後部と 中，下前頭回後半部を結ぶが，前頭葉後部と下頭頂小葉 

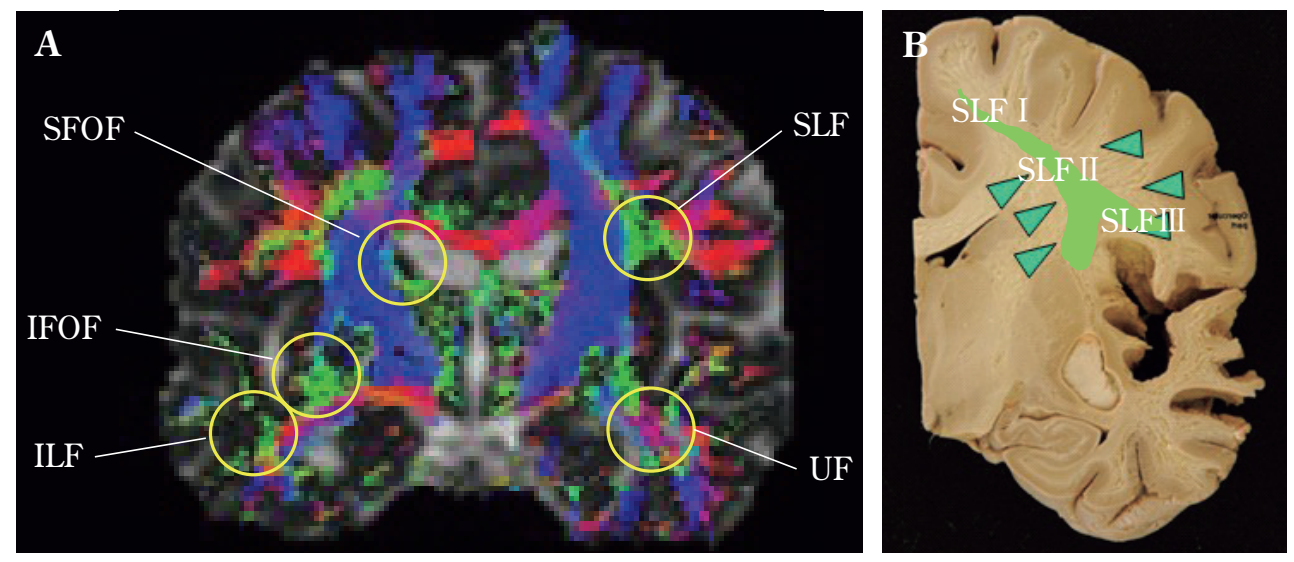

Fig. 3 A : Coronal section view of a 2D-color map by 3T-MRI.

B : Coronal section at the level of the rostrum of the corpus callous.

SFOF : superior fronto-occipital fasciculus, IFOF : inferior fronto-occipital fasciculus, ILF : inferior longitudinal fasciculus, SLF : superior longitudinal fasciculus, UF : uncinated fasciculus

を結ぶ前頭部分と, 下頭頂小葉と側頭部後半を結ぶ後半 部分に分かれる間接経路があることが示されている7). これらは下頭頂葉から上側頭回に位置する腫瘍の場合に 生じるさまざまな神経症状に関係する。たとえば縁上回 皮質の電気刺激にて音韻性錯語または構音の障害を示す が, 意味に関する障害は起こらないことが報告されてい る ${ }^{24)}$.このように弓状束周囲の解剖は複雑で, 報告によ り解釈が異なるために, 今後さらなる検討が待たれる ${ }^{6)}$.

\section{下前頭後頭束}

下前頭回と後頭極を連絡し，外包底部でレンズ核と銁 状束の間を通り中，下側頭回を連絡する．下縦束ととも に外包と最外包を形成する ${ }^{25)}$. 腹側ネットワークとも呼 ばれ, 統語の処理や文脈理解に関わる意味処理の遂行的 側面, 語彙の選択と意味記憶との関連づけなど, 単語レ ベルを超えるさまざまな言語の意味関連の処理に関与し ていると推定される $\left.{ }^{36} 37740\right) 41$. 側頭葉や後頭葉のみなら ず島回後方の摘出の際に近接する線維であり, 症状の鑑 別に注意を要する。

\section{下縦束}

側頭葉前部から起こり, 側脳室下角, 後角の外側を通つ て後頭葉後端に達する。側脳室三角部, 後角の外側では 視放線とともに外側矢状層に加わる.下前頭後頭束と下 縦束とは明瞭に分離することはできない. 本線維の障害 の場合, 外傷後の逆行性健忘のように記憶障害に関連す る症状が出現する4).

\section{銁状束}

島回の前下縁を経由し鉤状に曲がる線維束で，腹側成 分と背側成分に分けられる。腹側成分は前頭葉眼窩回と 側頭極，扁桃体，海馬回を連絡し，背側成分は中前頭回 付近と側頭葉前外側部を連絡して下前頭後頭束と合流す る。鉤状束は下前頭後頭束，視放線とともに temporal stem を構成し, 島回内の外包, 前障の外方下部を経由す る. 島回腫瘍の切除の場合に temporal stem について意 識する必要がある。この線維束はエピソード記憶や言語 の社会的な感情処理に関わる機能を有するとされてきた が，正確な機能についてはよくわかっていない，言語に おいては側頭葉前方と前頭葉底面の広い範囲とを結ぶ腹 側言語ネットワークの一部に属している。ただし，この 線維の損傷では直接言語機能に障害を及ぼすわけではな く, 直接言語機能障害を呈するものではなく ${ }^{11)}$, 言語の 意味関連の処理に関与していると考えられている ${ }^{6) 17)}$. 最近の研究では, 意思決定のための記憶表出と, ある種 の学習記憶の障害につながる可能性が示唆されてい る ${ }^{9)}$. 経験的には物品呼称にて刺激により音韻性錯語を 呈するが，下前頭葉を含む下前頭後頭束による腹側ネッ トワークが保たれているかぎり，永続的な言語障害につ ながるものではないようである。

\section{電気刺激により生じる naming error}

グリオーマに対する覚醒下手術では，皮質や白質への 直接刺激により誘発される症状から, 失語の夕イプや刺 激を受けた言語関連線維を想定しなければならない28). 
Table 2 Type of naming error ${ }^{8)}$

1. Semantic paraphasias

1. Coordinate

2. Associate

3. Superordinate

4. Subordinate

5. Part-whole

6. Visual

2. Circumlocution error

3. Phonological paraphasias

1. Substitution

2. Epenthesis

3. Deletion

4. Transposition

5. Perseveration

4. Neologism

5. Performance error

覚醒下手術中にわれわれが遭遇する失語症状の多くの場 合は典型的な失語症状を呈さない場合も多い。ガイドラ インにおいても刺激時のタスクの手順として数唱 (counting), 物品呼称 (naming), 読字 (reading) へと段 階的に進んでいくことで，失語の内容を選別することが 推奨されている ${ }^{21)}$. Ojemann $ら^{8)}$ の報告では覚醒下摘出 術中に遭遇する naming error の種類に関して 5 種類に 分類し, 生じる神経症状について詳しく解説しているの で参照されたい（Table 2).

\section{前方言語野白質}

前頭葉から側頭葉に主座する病巣の場合, 上縦束, 下 前頭後頭束，鈎状束が補足運動野，前頭言語野（いわゆ る Broca 野), 側頭葉を連絡する.上縦束は側脳室前角の 外側を走行し，上向する下前頭側頭束とともに補足運動 野との連絡に関与する ${ }^{113)}$. 前頭葉言語野の電気刺激に よって発語停止, 呼称障害, 復唱障害に加えて理解障害 が誘発される2238)。これとは対照的に, 前頭葉深部白質 の手術で生じる可能性の高い超皮質性運動失語の特徴 は, 自発性が著しく低下した発話, 良好な復唱能力, 比 較的良好な理解能力である。発話の自発性の低下やたく さんの呼称などの語想起課題の障害は, これら補足運動 野への連絡線維による影響が考えられている27)。この場 合には復唱や呼称は比較的良好である。島回から側頭葉 への操作の場合には，発語失行を伴う非流暢な発話，復 唱が障害される運動性失語を呈する場合がある．聴覚理 解は比較的保たれるが，発話に関して喚語困難，錯語が
みられ，呼称は障害されるも語頭音ヒントが有効な場合 も多い. 前頭葉言語野の後部下方は音韻から構音への変 換に関与していると考えられ，発話の最終処理としての 音声を構音する領域が中心前回の中〜下部である。この 両者をつなぐ領域には刺激にて運動停止を誘発する陰性 運動野が確認できる場合がある。この部位の損傷ではし ばしば流暢性の乏しい断続言語様の症状がみられる。た だし，発語の障害が長期間持続することは少なく，前方 言語野として機能的に重要な連絡線維は前頭葉言語野と 補足運動野とを結ぶ経路とも考えられている27)33).なお, 本邦では前頭葉損傷による超皮質性感覚失語が数多く報 告されている ${ }^{30)}$. 病巣は中，下前頭回後半部の皮質，皮 質下に多く，中心前回は基本的に保存さ机前頭葉言語野 を一部または全部含むことが多く，超皮質性運動失語を 生じる部位とオーバーラップする場合が多いようであ る。すなわち，前頭葉白質病変では超皮質性運動失語， 感覚失語いずれもが起こり得ることを記憶しておきた (18).

症例 1 は, Wada test にて左優位半球が判定している 島回〜側頭葉内側に主座する 25 歳の神経膠腫 (oligoastrocytoma）症例である（Fig. 4)。てんかん発作にて発症 した失語症状を伴わない術前無症状な症例で，言語機能 温存を目的とした覚醒下手術が行われた。側頭葉内側部 分の摘出の際に一過性に保続，字性錯語が出現した。症 状は一過性であったために，覚醒手術を継続し，島回部 分の摘出を行った。島回後方下部に至ったところで物品 呼称にて無関連性錯語，保続を主体とした言語症状をき たした。側頭葉内側部分で生じた症状は，鉤から海馬へ の境界領域の摘出において鉤状束に起因し，島回後方で は temporal stem のうち下前頭後頭束に起因する症状と 考えられた。

\section{後方言語野白質}

頭頂葉に主座する症例では，緑上回深部に走行する弓 状束および下前頭後頭束が腫瘍の前方深部を走行するこ とが想定される。弓状束は上側頭回後部の側頭葉言語野 (いわゆる Wernicke 野) と下前頭回後部の前頭葉言語野 とを連絡する復唱の経路と考えられ2), 緑上回への刺激 では音韻性錯語または構音の障害を示し，深部では通過 する弓状束による伝導失語を呈する ${ }^{24) 35)}$ ，また，頭頂葉 言語野である角回は意味処理に関して賦活される部位で あり ${ }^{3)}$ ，刺激では計算障害や Gerstmann 症候群を呈す $3^{10) 34)}$ 。一方，弓状束のみの障害では一過性の伝導失語 しか起こさない可能性が指摘されており ${ }^{39)}$ ，理解障害を 


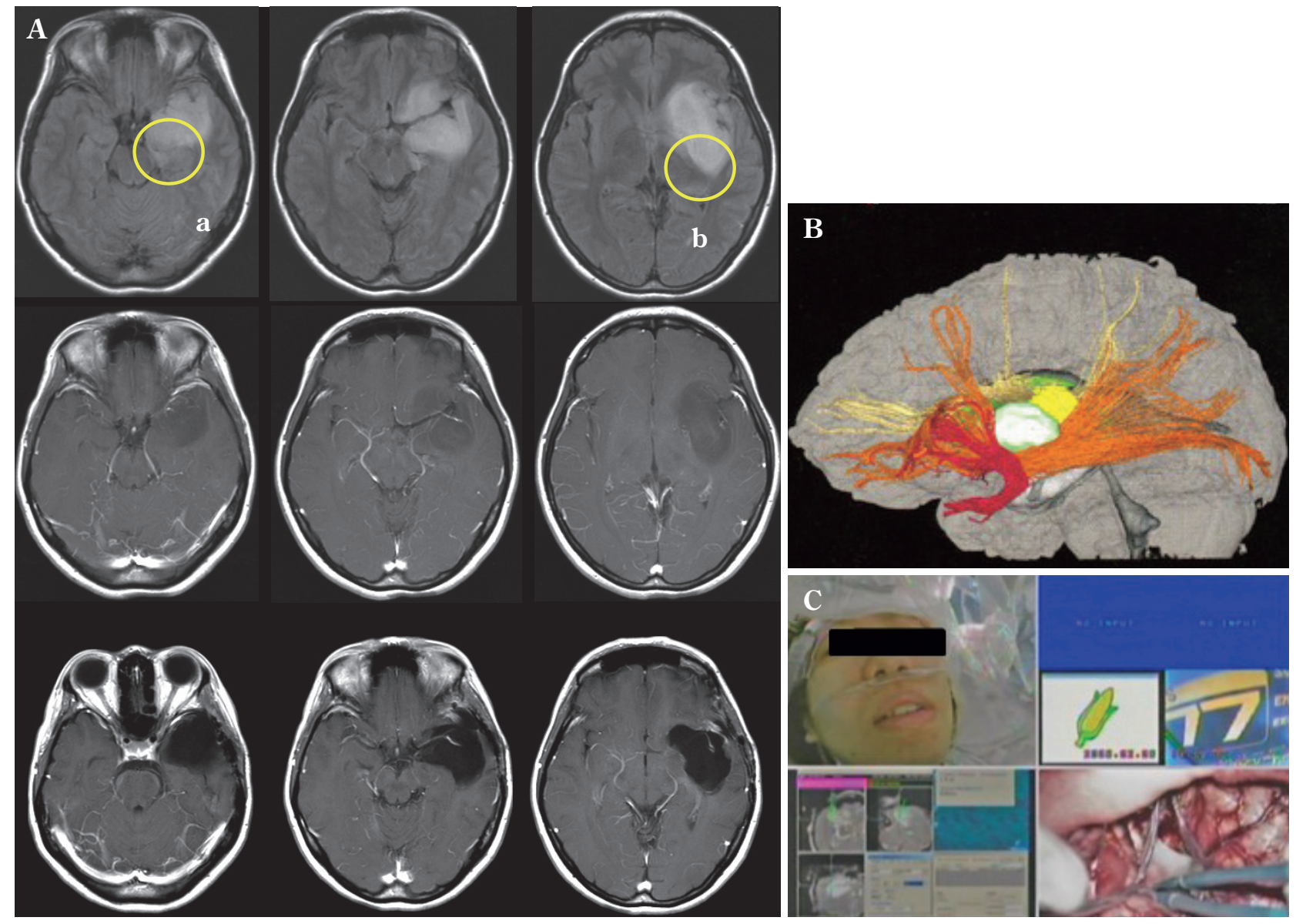

Fig. 4 A : Pre- and post-surgical removal of Lt frontal oligoastrocytoma.

Upper lane, pre-operative MRI image of axial FLAIR.

Middle lane, pre-operative MRI of axial T1-Gd.

Lower lane, post-operative MRI of axial T1-Gd.

(a) Repetition and paraphasia caused by uncinated fasciculus.

(b) Semantic jargon aphasia caused by IFOF.

B : 3D model of association fiber. Red ; uncinate fiber, Brown ; IFOF

C : Semantic jargon aphasia during posterior part of insula tumor removal.

生じない範囲で縁上回から側頭頭頂接合部を含む皮質, 皮質下病巣により伝導失語を呈するとも考えられてい る ${ }^{15)}$. 最近の研究では弓状束は上, 中側頭回後部と中, 下前頭回後部ならびに中心前回とを連絡する一方で，必 ずしも前頭葉言語野に終止しない場合やその後部の弁蓋 部までしか至らない場合があることも報告されている.

Tractography が交叉線維を描出できないことによる可能 性があるため, 今後の研究結果が待たれる7)14).

術中にみられる症状の特徵は, 自発話は基本的に流暢 であり，音韻性錯語がしばしば頻発するが発語失行はな く, 語性錯語は少ない。復唱障害は特徵的であり, 頻発 する音韻性錯語に対する自己修復が繰り返される傾向が みられる、喚語できているが音韻性錯語によって正しい 表出が妨げられ，言い直すのが伝導失語の特徵とされ
る ${ }^{19)}$ ．聴覚性理解障害はほとんどないが，呼称において 仮名の字性錯読が強い傾向である ${ }^{29)}$.

症例 2 は，優位半球下部頭頂葉に主座する神経膠腫で ある（Fig. 5)。てんかん発作にて発症した，術前失語症 状のない症例で, 硬膜下電極留置による皮質マッピング を行い, 腫瘍直上に誘発される神経症状は認めないこと を確認した。腫瘍前方下部，縁上回深部の白質部分の摘 出の際に, 流暢性, 長文の復唱の障害, 無関連性錯語, 仮名読字障害を呈した。解剖学的には深部白質の弓状束 に関連する症状と考えられた。

\section{おわりに}

3T MRI の普及により拡散テンソル画像を用いた神経 

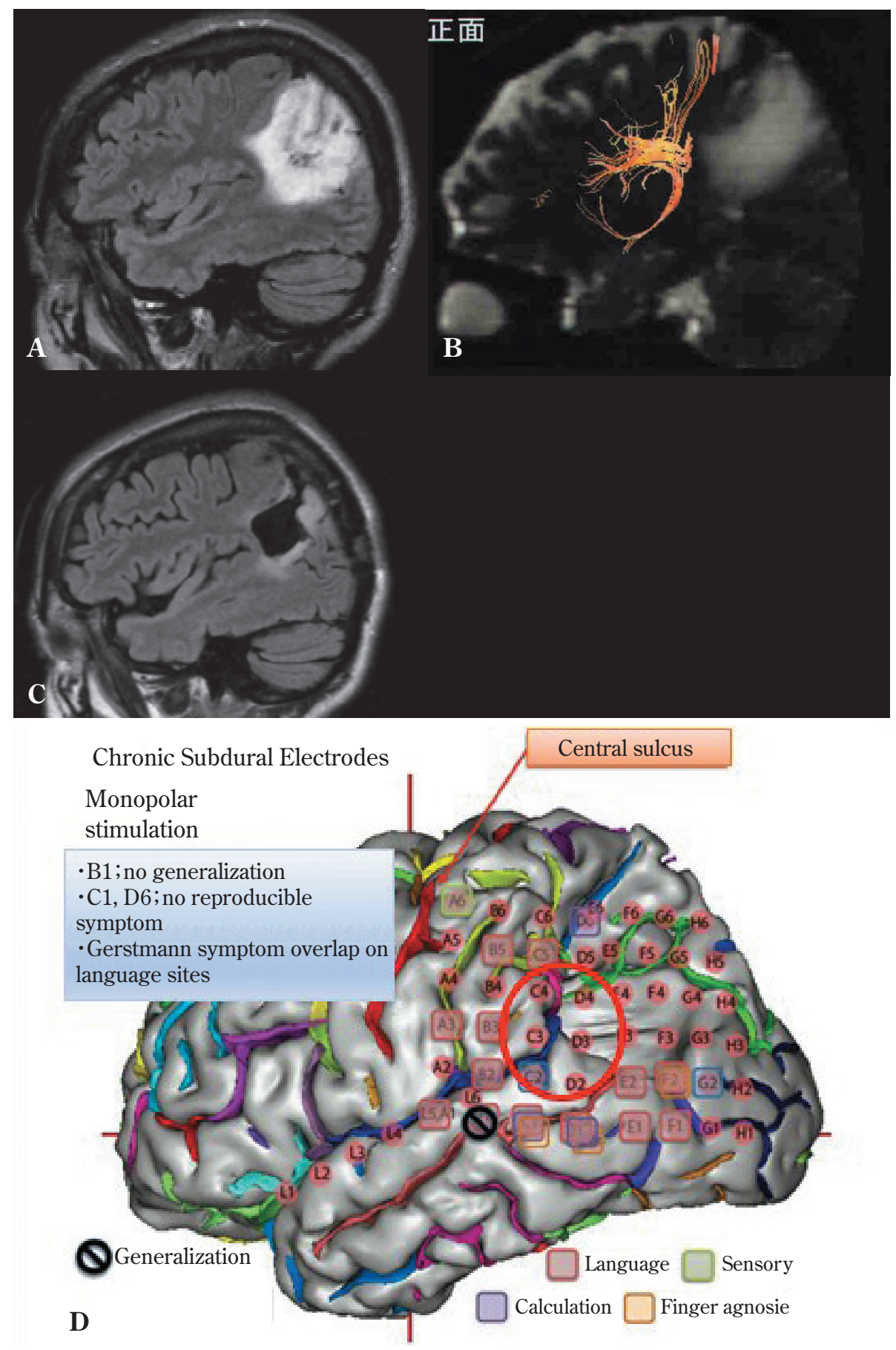

Fig. 5 Pre- and post-surgical removal of a Lt parietal anaplastic oligodendroglioma
A : Preoperative sagittal FLAIR image.
B : Preoperative tractography indicating the arcuate fibers.
C : Postoperative sagittal FLAIR image.
D : Preoperative functional evaluation by grid-electrode implantation.

連絡線維の詳細な描出が可能となり, 神経膠腫手術の術

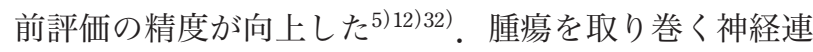
絡線維の走行を事前に予測することで, 言語領域に隣接
する腫瘍摘出において覚醒下手術による言語機能の評価 が可能となる。特に皮質下マッピングによる言語機能の 評価にて，生じた神経症状から神経線維の連続性の確認 
を行うことが重要である．皮質下部分の摘出の場合，わ れわれが多用するのは復唱と関連する呼称の語想起であ $3^{26)}$. 深部白質での摘出操作と並行して症状の誘発の有 無を確認することが理想的ではあるが，刺激と摘出を同 時に行うことは困難である。したがってモニタリングと して通常会話を継続しつつ流暢性や理解度, 反応性など の低下を感じた場合に，速やかに電気刺激によるマッピ ングを実施し，物品呼称，復唱，読字など想定される神 経線維に準じた言語反応の可否を確認する。ただし，観 察される神経症状は腫瘍の組織型, 罹患期間, サイズな どに多くの影響を受けることから，それぞれの症例にお いて綿密な予測と評価が必要である。また，合併症を予 防しつつ最大限の摘出を行うという目標達成のために は, 生じた神経症状が腫瘍摘出後に回復が可能か否かを 判断することも今後の課題である.

本稿では，覚醒下手術による術中マッピングの観点か ら大脳白質の神経線維の解剖と言語に関する神経症状に つき解説を行った。

\section{謝 辞}

本稿を執筆するにあたり，貴重なご指導を賜りました札幌 医科大学医学部リハビリテーション医学講座教授 石合純夫 教授に心より感謝申し上げます。

著者の COI（conflicts of interest）開示: 本論文の発表に 関して開示すべき COI はありません

\section{文 献}

1) Alexander MP, Benson DF, Stuss DT : Frontal lobes and language. Brain Lang 37 : 656-691, 1989.

2) Bernal B, Ardila $A$ : The role of the arcuate fasciculus in conduction aphasia. Brain 132:2309-2316, 2009.

3) Binder JR, Desai RH, Graves WW, Conant LL: Where is the semantic system? A critical review and meta-analysis of 120 functional neuroimaging studies. Cereb Cortex 19: 2767-2796, 2009.

4) Catani M, Jones DK, Donato R, Ffytche DH: Occipitotemporal connections in the human brain. Brain $\mathbf{1 2 6}$ : 2093-2107, 2003.

5) Catani M, Jones DK, Ffytche DH: Perisylvian language networks of the human brain. Ann Neurol 57:8-16, 2005.

6) Catani M, Mesulam $\mathrm{M}$ : The arcuate fasciculus and the disconnection theme in language and aphasia: history and current state. Cortex 44:953-961, 2008.

7) Catani M, Thiebaut de Schotten $M$ : A diffusion tensor imaging tractography atlas for virtual in vivo dissections. Cortex 44:1105-1132, 2008.

8) Corina DP, Loudermilk BC, Detwiler L, Martin RF, Brinkley JF, Ojemann G: Analysis of naming errors during cortical stimulation mapping: implications for models of language representation. Brain Lang 115:101-112, 2010 .
9) de Zubicaray GI, Rose SE, McMahon KL: The structure and connectivity of semantic memory in the healthy older adult brain. Neuroimage 54: 1488-1494, 2011.

10) Duffau H, Denvil D, Lopes M, Gasparini F, Cohen L, Capelle L, Van Effenterre R: Intraoperative mapping of the cortical areas involved in multiplication and subtraction: an electrostimulation study in a patient with a left parietal glioma. J Neurol Neurosurg Psychiatry 73:733738, 2002.

11) Duffau H, Gatignol P, Moritz-Gasser S, Mandonnet E : Is the left uncinate fasciculus essential for language? A cerebral stimulation study. J Neurol 256: 382-389, 2009.

12) Fernandez-Miranda JC, Pathak S, Engh J, Jarbo K, Verstynen T, Yeh FC, Wang Y, Mintz A, Boada F, Schneider W, Friedlander R: High-definition fiber tractography of the human brain: neuroanatomical validation and neurosurgical applications. Neurosurgery $\mathbf{7 1}:$ 430-453, 2012.

13) Freedman M, Alexander MP, Naeser MA: Anatomic basis of transcortical motor aphasia. Neurology 34:409-417, 1984.

14) Frey S, Campbell JS, Pike GB, Petrides M: Dissociating the human language pathways with high angular resolution diffusion fiber tractography. J Neurosci 28: 1143511444, 2008.

15) Fridriksson J, Kjartansson O, Morgan PS, Hjaltason H, Magnusdottir S, Bonilha L, Rorden C: Impaired speech repetition and left parietal lobe damage. J Neurosci $\mathbf{3 0}$ : 11057-11061, 2010.

16) Giussani C, Roux FE, Ojemann J, Sganzerla EP, Pirillo D, Papagno $\mathrm{C}:$ Is preoperative functional magnetic resonance imaging reliable for language areas mapping in brain tumor surgery? Review of language functional magnetic resonance imaging and direct cortical stimulation correlation studies. Neurosurgery $66: 113-120,2010$.

17) Grossman M, McMillan C, Moore P, Ding L, Glosser G, Work M, Gee J: What's in a name: voxel-based morphometric analyses of MRI and naming difficulty in Alzheimer's disease, frontotemporal dementia and corticobasal degeneration. Brain 127:628-649, 2004.

18）濱中淑彦，波多野和夫，石黒聖子，橋本眞言，辻 麻子, 田中春美，三宅裕子，石川佐和夫，太田彰子，中嶋理香， 松井朋子：前頭葉と失語一超皮質性感覚失語像をめぐつ て一。失語症研究 12:130-144，1992.

19）石合純夫：高次脳機能障害学 第 2 版. 東京, 医歯薬出 版, 2012 .

20) Jbabdi S, Johansen-Berg H: Tractography: where do we go from here? Brain Connect 1: 169-183, 2011.

21) Kayama $T$; Guidelines Committee of the Japan awake surgery conference: The guidelines for awake craniotomy guidelines committee of the Japan awake surgery conference. Neurol Med Chir (Tokyo) 52: 119-141, 2012.

22) Lesser RP, Lueders H, Dinner DS, Hahn J, Cohen L: The location of speech and writing functions in the frontal language area. Results of extraoperative cortical stimulation. Brain 107 (Pt 1) : 275-291, 1984.

23) Makris N, Kennedy DN, McInerney S, Sorensen AG, Wang R, Caviness VS Jr, Pandya DN: Segmentation of subcomponents within the superior longitudinal fascicle in humans: a quantitative, in vivo, DT-MRI study. Cereb Cortex 15:854-869, 2005.

24) Maldonado IL, Moritz-Gasser S, Duffau H : Does the left superior longitudinal fascicle subserve language seman- 
tics? A brain electrostimulation study. Brain Struct Funct 216: 263-274, 2011.

25) Mandonnet E, Nouet A, Gatignol P, Capelle L, Duffau H : Does the left inferior longitudinal fasciculus play a role in language? A brain stimulation study. Brain 130:623629, 2007.

26）丸山隆志，村垣善浩，新田雅之，齋藤太一，田村 学, 伊関 洋, 岡田芳和: 覚醒下手術の現状と課題. 脳外誌 22: 597-604, 2013.

27) Morgan VL, Mishra A, Newton AT, Gore JC, Ding Z: Integrating functional and diffusion magnetic resonance imaging for analysis of structure-function relationship in the human language network. PLoS One 4: e6660, 2009.

28）村垣善浩：脳機能マッピング・モニタリング 硬膜下電 極モニタリング法を用いた機能部位同定の要点と注意 点. 脳外誌 $10: 291,2001$.

29）永江和久：失読症における失読。神経内科 10：437442,1979 .

30）大梘美佳，相馬芳明，吉村菜穂子，小山 晃，辻 省次： 前頭葉損傷と理解障害一前頭葉損傷による流暢性失語に おける検討一. Brain Nerve 49: 122-130，1997.

31) Price CJ: The anatomy of language: a review of 100 fMRI studies published in 2009. Ann NY Acad Sci 1191: 62-88, 2010.

32) Richter M, Zolal A, Ganslandt O, Buchfelder M, Nimsky $\mathrm{C}$, Merhof D: Evaluation of diffusion-tensor imagingbased global search and tractography for tumor surgery close to the language system. PLoS One 8: e50132, 2013.

33) Rosso C, Valabregue R, Arbizu C, Ferrieux S, Vargas P, Humbert F, Attal Y, Messé A, Zavanone C, Meunier S, Cohen L, Delmaire C, Thielscher A, Herz DM, Siebner HR, Samson Y, Lehéricy S: Connectivity between right inferior frontal gyrus and supplementary motor area predicts after-effects of right frontal cathodal tDCS on picture naming speed. Brain Stimul 7: 122-129, 2014.

34) Roux FE, Boetto S, Sacko O, Chollet F, Trémoulet M:
Writing, calculating, and finger recognition in the region of the angular gyrus: a cortical stimulation study of Gerstmann syndrome. J Neurosurg 99: 716-727, 2003.

35) Roux FE, Lubrano V, Lauwers-Cances V, Trémoulet M, Mascott CR, Démonet JF : Intra-operative mapping of cortical areas involved in reading in mono $^{-}$and bilingual patients. Brain 127: 1796-1810, 2004.

36) Saur D, Kreher BW, Schnell S, Kümmerer D, Kellmeyer P, Vry MS, Umarova R, Musso M, Glauche V, Abel S, Huber W, Rijntjes M, Hennig J, Weiller C: Ventral and dorsal pathways for language. Proc Natl Acad Sci U S A 105 : 18035-18040, 2008.

37) Saur D, Schelter B, Schnell S, Kratochvil D, Küpper H, Kellmeyer P, Kümmerer D, Klöppel S, Glauche V, Lange R, Mader W, Feess D, Timmer J, Weiller C: Combining functional and anatomical connectivity reveals brain networks for auditory language comprehension. Neuroimage 49: 3187-3197, 2010.

38) Schäffler L, Lüders HO, Dinner DS, Lesser RP, Chelune GJ : Comprehension deficits elicited by electrical stimulation of Broca's area. Brain 116 (Pt 3) : 695-715, 1993.

39) Tanabe H, Sawada T, Inoue N, Ogawa M, Kuriyama Y, Shiraishi J: Conduction aphasia and arcuate fasciculus. Acta Neurol Scand 76:422-427, 1987.

40) Tyler LK, Marslen-Wilson W : Fronto-temporal brain systems supporting spoken language comprehension. Philos Trans R Soc Lond B Biol Sci 363 : 1037-1054, 2008.

41) Tyler LK, Marslen-Wilson WD, Randall B, Wright P, Devereux BJ, Zhuang J, Papoutsi M, Stamatakis EA : Left inferior frontal cortex and syntax: function, structure and behaviour in patients with left hemisphere damage. Brain 134 (Pt 2) : 415-431, 2011.

42) Yasargil MG : Microneurosurgery IVA : CNS Tumors : Surgical Anatomy, Neuropathology, Neuroradiology, Neurophysiology, Clinical Considerations, Operability, Treatment Options. New York, Thieme, 1994.

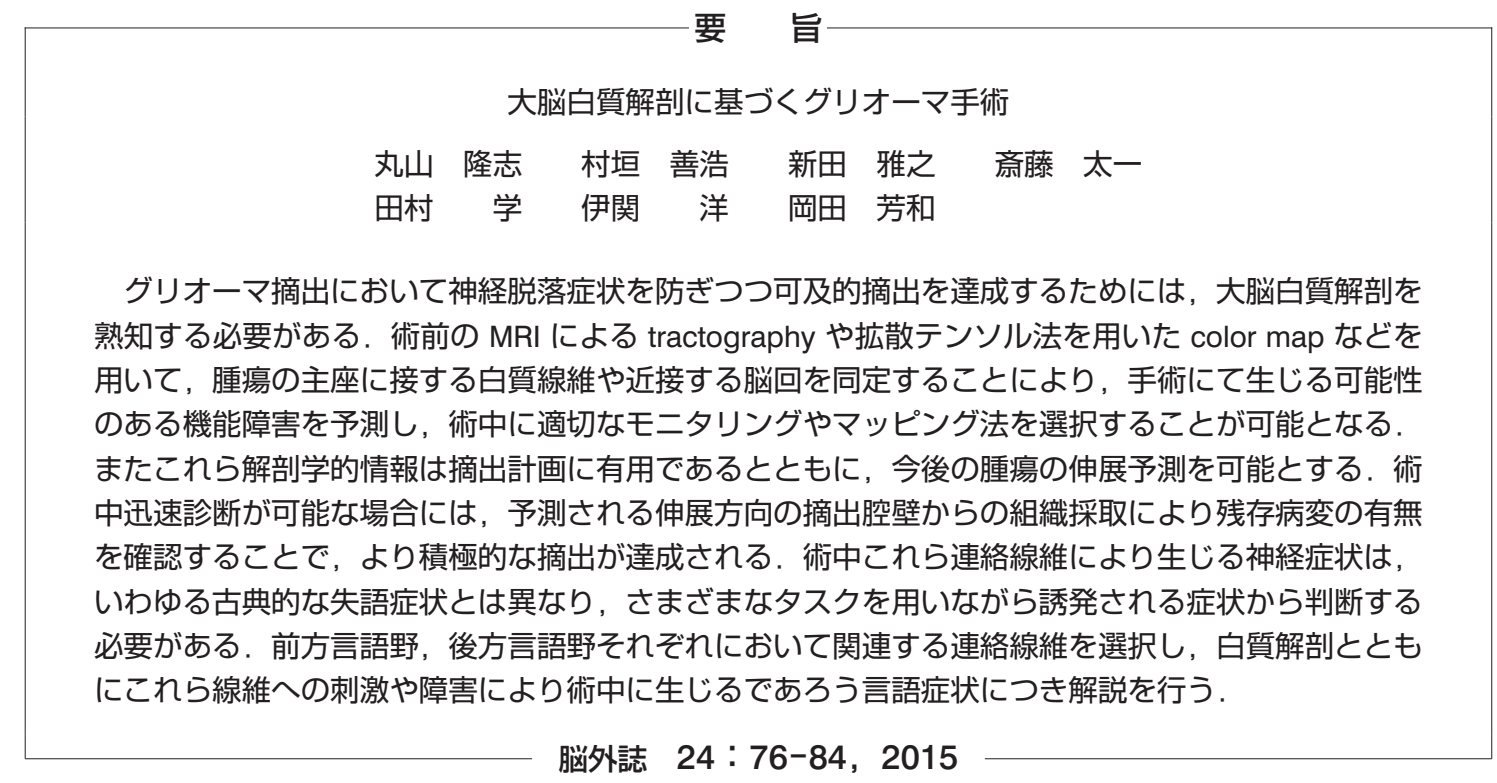

